\title{
Pengaruh Pembangunan Perumahan Bagi Rumah Tangga Miskin (RTM) Terhadap Kondisi Sosial- Ekonomi Masyarakat Kelurahan Sawah Besar, Kecamatan Gayamsari, Kota Semarang
}

\section{Maharani Tri Hapsari}

Diterima : 28 Juni 2016

Disetujui : 18 Juli 2016

\begin{abstract}
This research is motivated by the problems there is the number of poor people in Central Java who live in the houses not livable. Therefore, Central Java Provincial Government made a Housing Development Program for Poor Households. Central Java province has been conducting monitoring and evaluation of the program, but is only the aspect of a physicaly output, whereas according to the concept Tridaya that housing construction should also touching the social and economic conditions of society, so the researchers are interested in conduct research on how the influence of the development program of housing for poor households to the socio-economic condition of society in Kelurahan Sawah Besar, Kecamatan Gayamsari Kota Semarang. The research methodology used in this study is a mixture of qualitative and quantitative descriptive analysis with nonparametric statistical methods using statistical test of Wilcoxon different test as well as the influence of the Pearson correlation test using SPSS version 20. The conclusion is the average percentage of target accuracy analysis is based on the condition of households amounted to $31.50 \%$, while the results of the analysis target accuracy of the condition of the house building is at $68.75 \%$. As a result of the implementation of the program is able to improve the physical condition by $55 \%$, improving social conditions by $45 \%$, but the economic outlook has decreased by $10 \%$, due to a decrease in variable levels of spending, which is caused by the number of respondents who went into debt in the implementation of development / repair their house. Therefore, the need for revisions or changes in the criteria determining the target households, using of local wisdom, which is expected to generate empowerment in its implementation so as to avoid people from debt problems.
\end{abstract}

Keywords : Effects of Housing Development Program, Poor Households, Socio-Economic Conditions, House That Not Livable

\section{ABSTRAK}

Penelitian ini dilatarbelakangi oleh permasalahan masih banyaknya masyarakat miskin di Jawa Tengah yang tinggal di Rumah Tidak Layak Huni, sehingga Pemerintah Provinsi Jawa Tengah membuat suatu Program Pembangunan Perumahan bagi Rumah Tangga Miskin. Hasil yang diperoleh dari monitoring dan evaluasi terhadap program tersebut baru menggambarkan aspek output yang bersifat fisik, sedangkan sesuai konsep tridaya, harus pula menyentuh kondisi sosial dan ekonomi masyarakat, sehingga peneliti tertarik untuk melakukan penelitian tentang bagaimana pengaruh dari program terhadap kondisi sosial dan ekonomi masyarakat di Kelurahan Sawah Besar, Kecamatan Gayamsari, Kota Semarang. Metodologi penelitian yang digunakan adalah campuran antara analisis deskriptif kualitatif dan kuantitatif dengan metode statistik nonparametrik menggunakan uji statistik berupa uji beda dari Wilcoxon serta uji pengaruh korelasi Pearson dengan bantuan SPSS versi 20. Kesimpulan yang diperoleh adalah persentase rata-rata dari analisis ketepatan sasaran berdasarkan kondisi rumah tangga adalah sebesar 31,50\%, sedangkan hasil analisa ketepatan sasaran terhadap kondisi bangunan rumah yaitu $68,75 \%$. Hasil dari pelaksanaan program adalah meningkatkan kondisi fisik sebesar 55\%, meningkatkan kondisi sosial sebesar 45\%, tetapi terhadap kondisi ekonomi mengalami penurunan sebesar 10\%, diakibatkan oleh penurunan pada variabel tingkat pengeluaran, sebagai akibat dari banyaknya responden yang harus berhutang dalam pelaksanaan pembangunan/perbaikan rumahnya. Oleh karena itu, perlu adanya revisi atau perbaikan dalam penentuan kriteria rumah tangga sasaran, yaitu menggunakan kearifan lokal, sehingga diharapkan dapat membangkitkan pemberdayaan untuk dapat menghindarkan masyarakat dari permasalahan hutang.

Kata Kunci : Pengaruh Program Pembangunan Perumahan, Rumah Tangga Miskin, Kondisi Sosial Ekonomi,Rumah Tidak Layak Huni.

\section{PENDAHULUAN}

${ }^{1}$ Dinas Cipta Karya dan Tata Ruang Provinsi Jawa Tengah

Kontak Penulis : maharani_t@yahoo.com 
Tri Hapsari, M I Pengaruh Pembangunan Perumahan Bagi Rumah Tangga Miskin (Rtm) Terhadap Kondisi Sosial - Ekonomi Masyarakat Kelurahan Sawah Besar, Kecamatan Gayamsari, Kota Semarang

Permasalahan kemiskinan merupakan masalah mendasar yang menjadi beban bagi pemerintah di negara manapun terutama di negara yang sedang berkembang. Penyebab utama munculnya kemiskinan, utamanya di perkotaan adalah kemampuan ekonomi masyarakat yang rendah, sehingga menyulitkan bagi penduduk miskin untuk memperoleh pelayanan dasar perkotaan dari pemerintah, dimana pelayanan kota yang paling utama dan mendasar bagi masyarakat adalah pelayanan dasar yang berhubungan dengan aktivitas utama masyarakat, yaitu pangan, sandang, dan tempat tinggal.

Menurut Yudohusodo (1991), rumah adalah bangunan yang berfungsi sebagai tempat tinggal atau hunian dan sarana pembinaan keluarga. Jadi, selain berfungsi sebagai tempat tinggal atau hunian yang digunakan untuk berlindung dari gangguan iklim dan makhluk hidup lainnya, rumah merupakan tempat awal pengembangan kehidupan. Rumah yang tidak layak huni secara fisik, sosial, psikologis, akan mempengaruhi komunikasi dan relasi sosial anggota keluarga, kebiasaan, pola pikir, dan cara hidup, serta interaksi dengan lingkungan, sehingga situasi tersebut akan mempengaruhi produktivitas dari penghuni rumahnya, namun pada kenyataannya, tidak semua orang mampu memenuhi kebutuhan rumah yang layak huni karena alasan ekonomi atau kemiskinan.

Di Provinsi Jawa Tengah sendiri, terdapat rumah tangga sebanyak 8.913.425 rumah tangga, dimana sebanyak 2.793.948 rumah tangga merupakan rumah tangga miskin. Sebagian besar dari rumah tangga miskin tersebut masih menempati rumah yang kurang layak huni, yaitu sekitar 2.053.772 rumah tangga, dimana bangunan rumahnya ber-type $C$, yaitu bangunan rumah yang masih berlantai tanah, beratap ijuk / rumbia dan berdinding bambu (Jawa Tengah Dalam Angka, 2013). Oleh karena itu, memperhatikan visi dan arah kebijakan pembangunan Provinsi Jawa Tengah saat ini, maka muncullah suatu program pembangunan perumahan dan pemberdayaan komunitas perumahan yang berkaitan dengan perbaikan kualitas Rumah Tidak Layak Huni (RTLH) utamanya bagi masyarakat miskin, dimana program tersebut bersinergi dengan program penanggulangan kemiskinan yang dicanangkan oleh Provinsi Jawa Tengah yaitu kegiatan fasilitasi dan stimulan pembangunan perumahan swadaya bagi Rumah Tangga Miskin (RTM).

Kegiatan fasilitasi dan stimulan pembangunan perumahan swadaya bagi Rumah Tangga Miskin (RTM) merupakan suatu kegiatan yang bersifat pendorong untuk membantu Rumah Tangga Miskin (RTM) memperbaiki rumahnya sehingga menjadi lebih layak huni, dimana pemanfaatan pemberian stimulan digunakan untuk memperbaiki komponen yang berkaitan dengan perkuatan konstruksi dan kesehatan, antara lain: jendela, lantai, dinding, atap, pondasi dan kolom, sehingga diharapkan dapat semakin meningkatkan jumlah rumah layak huni/sehat di Provinsi Jawa Tengah, serta secara tidak langsung mampu menurunkan angka kemiskinan/berkurangnya jumlah Rumah Tangga Miskin (RTM) di Provinsi Jawa Tengah.

Konsep Tridaya pembangunan perumahan yang berkelanjutan pada hakekatnya merupakan pemberdayaan yang terintegrasi, yaitu pemberdayaan manusia seutuhnya agar mampu membangkitkan ketiga daya yang telah dimiliki manusia secara integratif, yaitu daya pembangunan agar tercipta masyarakat yang peduli dengan pembangunan perumahan dan permukiman yang berorientasi pada kelestarian lingkungan, daya sosial agar tercipta masyarakat yang efektif secara sosial, dan daya ekonomi agar tercipta masyarakat produktif secara ekonomi.

Setelah berlangsungnya kegiatan tersebut, Provinsi Jawa Tengah telah melakukan monitoring dan evaluasi, namun demikian hasil monitoring dan evaluasi yang dilakukan baru menggambarkan aspek output yang bersifat fisik saja belum secara sosial maupun ekonomi, padahal sesuai konsep 
JPWK 12 (3) Tri Hapsari, M I Pengaruh Pembangunan Perumahan Bagi Rumah Tangga Miskin (Rtm) Terhadap Kondisi Sosial - Ekonomi Masyarakat Kelurahan Sawah Besar, Kecamatan Gayamsari, Kota Semarang

tridaya pembangunan perumahan yang berkelanjutan, bahwa pembangunan perumahan harus pula menyentuh kondisi sosial dan ekonomi masyarakat, maka kiranya menarik untuk diadakan penelitian tentang pengaruh dari program pembangunan perumahan bagi rumah tangga miskin baik terhadap kondisi sosial maupun ekonomi masyarakat di Kelurahan Sawah Besar, Kecamatan Gayamsari, Kota Semarang, sebagai salah satu kelurahan yang menjadi prioritas pertama dalam penanggulangan kemiskinan di Kota Semarang.

\section{GAMBARAN UMUM WILAYAH STUDI}

Kota Semarang memiliki luas wilayah $373,70 \mathrm{~km}^{2}$. Secara administrative, Kota Semarang terbagi menjadi 16 (enam belas) kecamatan dan 177 kelurahan. Dari 16 (enam belas) kecamatan yang ada, terdapat 2 (dua) kecamatan yang mempunyai wilayah terluas yaitu Kecamatan Mijen, dengan luas wilayah 57,55 km² dan Kecamatan Gunungpati, dengan luas wilayah 54,11 km², sedangkan kecamatan yang mempunyai luas terkecil adalah Kecamatan Semarang Selatan dengan luas wilayah 5,93 km², diikuti oleh Kecamatan Semarang Tengah dengan luas wilayah 6,14 km².

Kecamatan Gayamsari memiliki luas wilayah $6,36 \mathrm{Km}^{2}$ yang secara administratif terbagi menjadi 7 (tujuh) Kelurahan, yaitu: Kelurahan Tambakrejo, Kelurahan Kaligawe, Kelurahan Pandean Lamper, Kelurahan Gayamsari, Kelurahan Siwalan, Kelurahan Sambirejo, dan Kelurahan Sawah Besar. Kelurahan Sawah Besar termasuk dalam kecamatan Gayamsari kota Semarang, terletak $5 \mathrm{~m}$ di atas permukaan laut dengan suhu maksimum dan minimum berkisar antara $45^{\circ} \mathrm{C}-32^{\circ} \mathrm{C}$ dengan dataran rendah. Kelurahan Sawah Besar memiliki luas wilayah 55 ha, adapun pembagian wilayah administrasi kelurahan Sawah Besar terdiri dari 42 unit RT dan 9 unit RW.

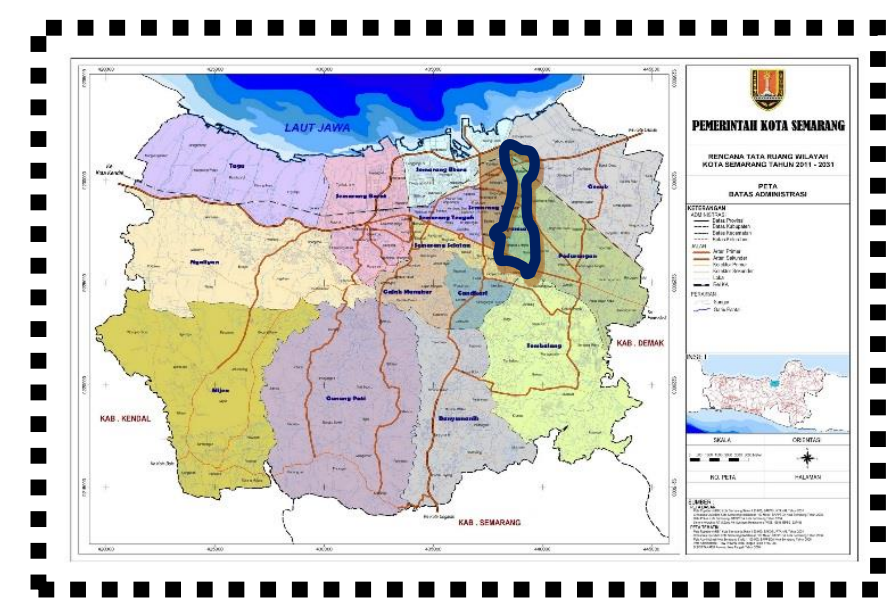

Sumber: Kota Semarang Dalam Angka, 2012

GAMBAR 1.

KELURAHAN SAWAH BESAR

\section{METODE PENELITIAN}

Dalam penelitian ini peneliti menggunakan pendekatan penelitian positivistik, yang basisnya mengaplikasikan teori mengenai pengaruh dari kegiatan secara umum yang dikaitkan dengan kondisi sosial dan ekonomi masyarakat. Dalam perkembangannya, pendekatan positivistik ini meluas maknanya menjadi pendekatan postpositivistik rasionalistik, yaitu dari kebenaran empirik 
Tri Hapsari, M | Pengaruh Pembangunan Perumahan Bagi Rumah Tangga Miskin (Rtm) Terhadap Kondisi Sosial - Ekonomi Masyarakat Kelurahan Sawah Besar, Kecamatan Gayamsari, Kota Semarang

JPWK 12 (3)

analitik, kemudian dipayungi oleh suatu grand concepts, agar data empirik tersebut dapat dimaknai dengan cakupan yang lebih luas. Metode penelitian yang digunakan adalah metode penelitian campuran (kuantitatif dan kualitatif). Teknik sampling yang digunakan adalah teknik sensus, karena semua populasi digunakan sebagai sampel. Teknik pengumpulan data dalam penelitian ini menggunakan teknik pengumpulan data primer yang terdiri dari: kuesioner, wawancara, dan observasi lapangan, dan teknik pengumpulan data sekunder yang terdiri dari: studi literatur dan studi dokumen.

Dalam penelitian ini, deskripsi kualitatif digunakan untuk mendeskripsikan/mengidentifikasi program pembangunan perumahan dan karakteristik rumah tangga sasaran, serta untuk menganalisis ketepatan sasaran dari rumah tangga penerima bantuan. Uji beda Wilcoxon digunakan untuk menganalisis perubahan kondisi fisik hunian/tempat tinggal, perubahan kondisi sosial dan ekonomi masyarakat penerima bantuan sedangkan uji korelasi Pearson digunakan untuk menganalisis pengaruh program terhadap kondisi sosial dan ekonomi masyarakat penerima bantuan.

\section{KAJIAN PENGARUH PEMBANGUNAN PERUMAHAN BAGI RUMAH TANGGA MISKIN (RTM) TERHADAP KONDISI SOSIAL-EKONOMI}

Kemiskinan merupakan sebuah konsep abstrak yang dapat dijelaskan secara berbeda dimana tergantung dari pengalaman dan perspektif analis. menurut World Bank setidaknya ada tiga faktor utama penyebab kemiskinan, yaitu:

1. Rendahnya pendapatan dan aset untuk memenuhi kebutuhan dasar, seperti: makanan, tempat tinggal, pakaian, kesehatan dan pendidikan.

2. Ketidakmampuan untuk bersuara dan ketiadaan kekuatan didepan institusi negara dan masyarakat.

3. Rentan terhadap guncangan ekonomi, terkait dengan ketidakmampuan menanggulanginya.

Berdasarkan UU no 1 tahun 2011 tentang perumahan dan permukiman, disebutkan bahwa perumahan adalah kelompok rumah yang berfungsi sebagai lingkungan tempat tinggal atau lingkungan hunian yang dilengkapi dengan prasarana dan sarana lingkungan. Pembangunan perumahan adalah suatu proses yang menciptakan suatu hubungan secara berkelanjutan antara ruang hidup di lingkungan masyarakat dan alam sekitarnya, sehingga perumahan tidak hanya dipandang sebagai benda mati atau sarana kehidupan semata (Yudohusodo, 1991).

Menurut Turner (1997), syarat sebuah rumah adalah minimal memenuhi 3 (tiga) kategori, yaitu: akses, dimana rumah dapat memudahkan pemakai untuk mencari penghasilan, berteduh yaitu rumah dapat memberi perlindungan dari iklim, dan kondisi fisik yaitu sejauh mana kondisi rumah dapat menjadi lebih layak huni. Menurut UU no 1/2011 dijelaskan bahwa rumah merupakan bangunan yang dimanfaatkan sebagai tempat berlindung dan penghidupan keluarga dalam lingkungan yang sehat, aman, serasi, dan teratur.

Menurut Peraturan Menteri Perumahan Rakyat No.22/PERMEN/M/2008 kualitas lingkungan perumahan adalah usaha yang dilakukan pemerintah, dalam meningkatkan kondisi perumahan dari yang tidak layak menjadi layak huni. Rumah layak huni adalah cakupan pemenuhan kebutuhan rumah yang memenuhi persyaratan keselamatan bangunan dan kecukupan minimum luas bangunan serta kesehatan penghuninya. 
JPWK 12 (3) Tri Hapsari, M I Pengaruh Pembangunan Perumahan Bagi Rumah Tangga Miskin (Rtm) Terhadap Kondisi Sosial - Ekonomi Masyarakat Kelurahan Sawah Besar, Kecamatan Gayamsari, Kota Semarang

Pengertian dari kegiatan fasilitasi dan stimulan pembangunan perumahan swadaya bagi Rumah Tangga Miskin (RTM) adalah suatu kegiatan pemberian stimulan bantuan sejumlah bahan/material bangunan dari Pemerintah Provinsi Jawa Tengah kepada rumah tangga yang sesuai dengan kriteria Rumah Tangga Miskin (RTM) berdasarkan pada Pedoman Pelaksanaan dari Provinsi Jawa Tengah.

Beberapa sumber menyatakan bahwa program perbaikan rumah dan lingkungan permukiman berhubungan dengan kondisi sosial dan ekonomi masyarakat yang mendapat bantuan tersebut, antara lain sebagai berikut:
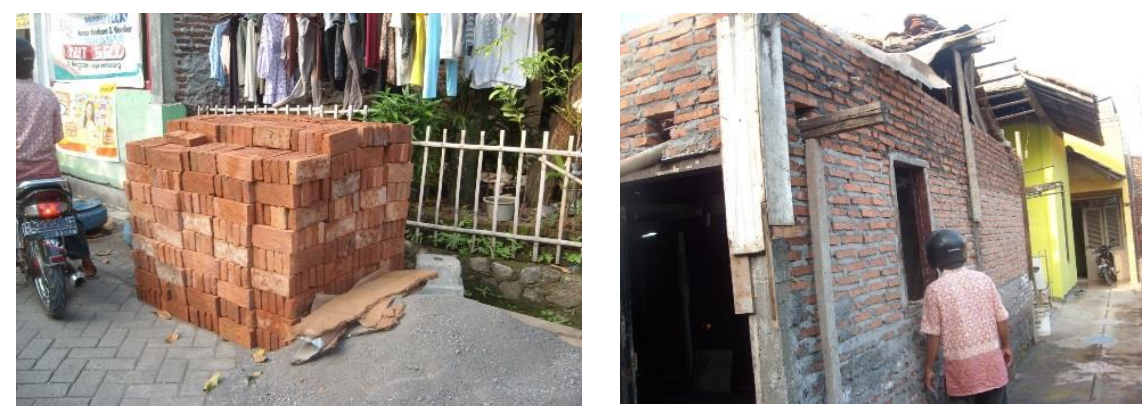

Sumber: Laporan Pelaksanaan Program, 2012

GAMBAR 2.

PROSES PELAKSANAAN KEGIATAN

- Budihardjo (1994), menyatakan bahwa dalam konteks rumah sendiri, kondisi sosial yang diharapkan dapat terpenuhi di dalam pemenuhan kebutuhan rumah secara layak adalah menyangkut aspek paguyuban, kekentalan komunitas, persepsi, aspirasi dan harapan penghuninya, selain itu, peran penting rumah sebagai kebutuhan sosial, berkaitan dengan pengaruh yang ditimbulkannya dalam hal kesejahteraan, kesehatan, dan tata cara berkeluarga atau bermasyarakat.

- Friedman (2010), menyatakan bahwa rumah yang tidak layak huni dapat memberi dampak pada kesehatan penghuni.

- Gambo et.al (2012), menyatakan bahwa terdapat hubungan yang kompleks antara kondisi fisik perumahan dengan kualitas pendidikan, keterjangkauan pelayanan kesehatan, dan tingkat pendapatan hingga menghambat dalam pengembangan perekonomian keluarga.

- Barnes et.al (2013), menyatakan bahwa kondisi dan kualitas rumah yang buruk memiliki hubungan yang erat dengan kesehatan.

- Frontier Economics (2014), menyatakan bahwa dari hasil penelitian menunjukkan bahwa dampak dari rumah yang layak huni dan terjangkau akan mempengaruhi beberapa hal di bidang sosial dan ekonomi, diantaranya adalah kesehatan, kejahatan, kemudahan dalam mencari pekerjaan/mata pencaharian, meningkatkan kesejahteraan dan kenyamanan, serta pendidikan. 
Tri Hapsari, M | Pengaruh Pembangunan Perumahan Bagi Rumah Tangga Miskin (Rtm) Terhadap Kondisi Sosial - Ekonomi Masyarakat Kelurahan Sawah Besar, Kecamatan Gayamsari, Kota Semarang

ANALISIS PENGARUH PEMBANGUNAN PERUMAHAN BAGI RUMAH TANGGA MISKIN (RTM) TERHADAP KONDISI SOSIAL-EKONOMI MASYARAKAT KELURAHAN SAWAH BESAR, KECAMATAN GAYAMSARI, KOTA SEMARANG

Data yang telah diperoleh melalui penelitian di lapangan untuk kemudian dianalisis berdasarkan literatur yang ada. Adapun analisis yang dilakukan terdiri dari 3 (tiga) analisis, yaitu :

Analisis Ketepatan Sasaran Masyarakat Penerima Bantuan

Analisis ketepatan sasaran masyarakat penerima bantuan terdiri dari 2 (dua) analisis, yaitu :

1. Analisis Ketepatan Sasaran Penerima Bantuan Berdasarkan Kondisi Rumah Tangga Sebelum Pelaksanaan Kegiatan

Persentase rata-rata dari analisa ketepatan sasaran berdasarkan kondisi rumah tangga sebelum pelaksanaan kegiatan adalah sebesar 31,50\%, dimana persentase tersebut masuk dalam kategori rendah karena kurang dari $50 \%$, hal tersebut bukan dikarenakan bahwa rumah tangga penerima bantuan dari kegiatan ini tidak memenuhi kriteria rumah tangga miskin atau tidak tepat sasaran, tetapi, karena kriteria yang digunakan dinilai masih belum mampu menangkap gambaran kemiskinan, serta memberikan hasil yang bias terhadap keadaan sebenarnya.

Penentuan kriteria dan cara pemilihan orang miskin yang tepat seperti pada preseden CODI di Thailand. Program kemiskinan ini mengakomodasi nilai-nilai demokrasi, dengan memberi ruang yang lebih luas pada keterlibatan masyarakat. Oleh karena itu, perlu adanya revisi atau perbaikan dalam penentuan kriteria rumah tangga sasaran, dimana kriteria rumah tangga sasaran yang lebih tepat adalah menggunakan kriteria kearifan lokal, yaitu kriteria miskin yang ditentukan oleh masyarakat sendiri secara demokratis, bukan secara intervensi dari pemerintah.

2. Analisis Ketepatan Sasaran Penerima Bantuan Berdasarkan Kondisi Bangunan Rumah Sebelum Pelaksanaan Kegiatan

Persentase hasil analisis ketepatan sasaran penerima bantuan berdasarkan kondisi rumah sebelum pelaksanaan program memiliki prosentase ketepatan sasaran rata-rata cukup tinggi yaitu sebesar $68,75 \%$.

Analisis Perubahan Kondisi Fisik, Sosial, dan Ekonomi Akibat dari Pelaksanaan Program

Analisis perubahan kondisi fisik, sosial, dan ekonomi akibat dari pelaksanaan program terdiri dari 3 (hal), yaitu :

1. Analisis Perubahan Kondisi Fisik Rumah Tangga Penerima Bantuan di Kelurahan Sawah Besar, Kecamatan Gayamsari, Kota semarang

Dari hasil uji Wilcoxon diperoleh hasil bahwa Asymp.Sig (2-tailed) adalah 0,000<0,05, sehingga memiliki arti bahwa Ho diterima dan Ha ditolak, yaitu terdapat perbedaan kondisi fisik antara sebelum dan sesudah kegiatan, kemudian dipertajam dengan teknik skoring dengan hasil sebanyak $85 \%$ responden berada pada kategori tinggi, dimana sebelumnya hanya 30\% responden yang berada pada kategori tinggi, sehingga ada peningkatan kondisi fisik sebesar $55 \%$. 
JPWK 12 (3) Tri Hapsari, M I Pengaruh Pembangunan Perumahan Bagi Rumah Tangga Miskin (Rtm) Terhadap Kondisi Sosial - Ekonomi Masyarakat Kelurahan Sawah Besar, Kecamatan Gayamsari, Kota Semarang
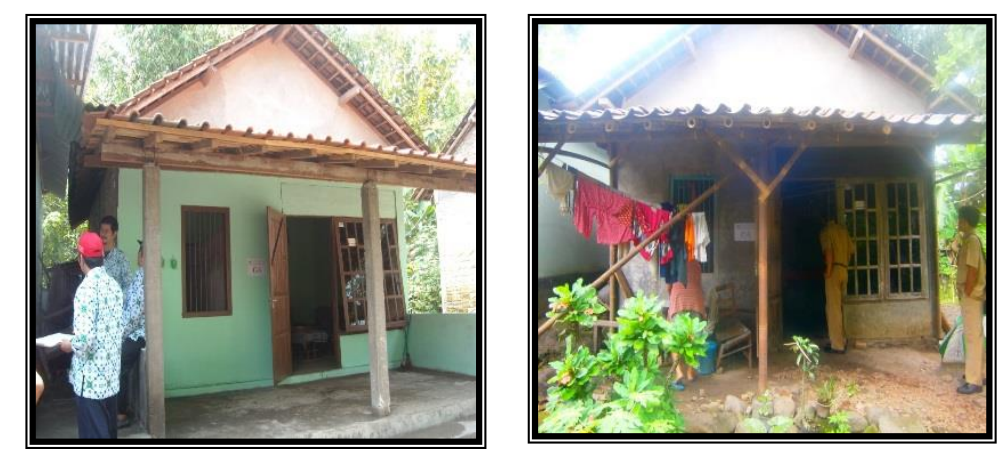

Sumber: Laporan Pelaksanaan Program, 2012

GAMBAR 3.

KONDISI SEBELUM DAN SESUDAH PELAKSANAAN PROGRAM

Oleh karena itu, program pembangunan bagi rumah tangga miskin memberikan perubahan yang positif terhadap kondisi fisik rumah dari para penerima bantuan.

2. Analisis Perubahan Kondisi Sosial Rumah Tangga Penerima Bantuan di Kelurahan Sawah Besar, Kecamatan Gayamsari, Kota semarang

Dari hasil uji Wilcoxon diperoleh hasil bahwa Asymp.Sig (2-tailed) adalah 0,001<0,05, sehingga memiliki arti bahwa Ho diterima, yaitu terdapat perbedaan kondisi sosial antara sebelum dan sesudah kegiatan, kemudian dipertajam dengan teknik skoring dengan hasil sebanyak $45 \%$ responden berada pada kategori tinggi, dimana sebelumnya tidak ada responden yang berada pada kategori tinggi, sehingga ada peningkatan kondisi sosial akibat dari pelaksanaan program sebesar $45 \%$.

Hal tersebut menunjukkan bahwa dengan adanya kegiatan ini cukup meningkatkan kondisi sosial mereka menjadi lebih baik, utamanya pada variabel partisipasi dan interaksi sosial.

3. Analisis Perubahan Kondisi Ekonomi Rumah Tangga Penerima Bantuan di Kelurahan Sawah Besar, Kecamatan Gayamsari, Kota semarang

Dari hasil uji Wilcoxon diperoleh hasil bahwa Asymp.Sig (2-tailed) adalah 0,952>0,05, sehingga memiliki arti bahwa Ho ditolak, yaitu tidak terdapat perbedaan kondisi ekonomi antara sebelum dan sesudah kegiatan, kemudian dipertajam dengan teknik skoring dengan hasil sebanyak $25 \%$ responden berada pada kategori tinggi, dimana sebelumnya terdapat sebanyak $35 \%$ responden yang berada pada kategori tinggi, hal tersebut menunjukkan bahwa adanya penurunan kondisi ekonomi akibat dari pelaksanaan program sebesar $10 \%$.

Untuk melihat secara detail dari tiap variabel kondisi ekonomi yang terpengaruh dari kegiatan ini, maka dilakukan pengujian pada tiap parameternya dengan menggunakan uji statistik Wilcoxon, yang diperoleh hasil sebagai berikut:

\section{- Perubahan Mata Pencaharian}

Dari hasil uji Wilcoxon diperoleh hasil bahwa Asymp.Sig (2-tailed) adalah 0,014<0,05, sehingga memiliki arti bahwa Ho diterima dan Ha ditolak, yaitu terdapat perbedaan parameter mata pencaharian antara sebelum dan sesudah kegiatan. 
Tri Hapsari, M I Pengaruh Pembangunan Perumahan Bagi Rumah Tangga Miskin (Rtm) Terhadap Kondisi Sosial - Ekonomi Masyarakat Kelurahan Sawah Besar, Kecamatan Gayamsari, Kota Semarang

JPWK 12 (3)

\section{- Perubahan Tingkat Pendapatan}

Dari hasil uji Wilcoxon diperoleh hasil bahwa Asymp.Sig (2-tailed) adalah 0,038<0,05, sehingga memiliki arti bahwa Ho diterima dan Ha ditolak, yaitu terdapat perbedaan pada parameter tingkat pendapatan antara sebelum dan sesudah kegiatan.

- Perubahan Tingkat Pengeluaran

Dari hasil uji Wilcoxon diperoleh hasil bahwa Asymp.Sig (2-tailed) adalah 0,670>0,05, sehingga memiliki arti bahwa Ho ditolak dan Ha diterima, yaitu tidak terdapat perbedaan yang signifikan pada parameter tingkat pengeluaran antara sebelum dan sesudah kegiatan.

Pada parameter tingkat pengeluaran, sangat signifikan tidak menampakkan perubahan dengan angka yang cukup besar yaitu $\mathbf{0 , 6 7 0}$, hal tersebut diakibatkan bahwa pengaruh dari pelaksanaan program terhadap pengeluaran responden, justru berbanding terbalik, dalam artian pengeluaran menjadi lebih besar dibandingkan sebelum adanya program, hal tersebut diakibatkan karena dalam pelaksanaan pembangunan/perbaikan rumah, banyak responden yang harus berhutang, sehingga mengakibatkan meningkatnya pengeluaran (berpengaruh negatif), karena tidak disediakan sharing dana dalam pelaksanaan pembangunannya.

\section{Analisis Pengaruh Program terhadap Kondisi Sosial dan Ekonomi Rumah Tangga Penerima Bantuan di Kelurahan Sawah Besar, Kecamatan Gayamsari, Kota Semarang}

Hasil analisis pengaruh program terhadap kondisi sosial dan ekonomi rumah tangga penerima bantuan dengan menggunakan analisis korelasi pearson diperoleh hasil sebagai berikut:

1. Nilai Sig. (2-tailed) antara pelaksanaan program dengan perubahan kondisi sosial adalah 0,761 , hal tersebut memiliki arti bahwa 0,761>0,05, sehingga Ho diterima dan Ha ditolak, yang berarti bahwa tidak ada hubungan/pengaruh secara signifikan antara perubahan kondisi fisik terhadap kondisi sosial, dengan tingkat korelasi 0,073, yang berarti memiliki korelasi sangat lemah

2. Nilai Sig. (2-tailed) antara pelaksanaan program dengan perubahan kondisi ekonomi adalah 0,041 , hal tersebut memiliki arti bahwa 0,041<0,05, sehingga Ho ditolak dan Ha diterima, yang berarti bahwa ada hubungan/pengaruh secara signifikan antara perubahan kondisi fisik terhadap kondisi ekonomi, dengan tingkat korelasi 0,461, yang berarti memiliki korelasi cukup

Oleh karena itu, dapat kita simpulkan, bahwa perubahan kondisi fisik bangunan sebagai hasil dari pelaksanaan program pembangunan perumahan bagi rumah tangga miskin, tidak berpengaruh terhadap perubahan kondisi sosial, tetapi berpengaruh pada kondisi ekonomi. Hasil analisis tersebut memiliki arti bahwa program ini lebih berpengaruh secara langsung terhadap kondisi ekonomi utamanya bagi masyarakat yang memiliki usaha sampingan di sekitar rumah, dimana penerima bantuan yang memiliki mata pencaharian sampingan dengan adanya program ini, dapat lebih mengembangkan usahanya sehingga dapat meningkatkan pendapatannya. Dari program ini pula, ternyata sangat berpengaruh secara langsung terhadap tingkat pengeluaran, karena seperti yang kita lihat pada uji beda sebelumnya, bahwa program ini menimbulkan biaya hutang dari beberapa penerima bantuan, diakibatkan tidak adanya sharing dari pemerintah. 
JPWK 12 (3) Tri Hapsari, M I Pengaruh Pembangunan Perumahan Bagi Rumah Tangga Miskin (Rtm) Terhadap Kondisi Sosial - Ekonomi Masyarakat Kelurahan Sawah Besar, Kecamatan Gayamsari, Kota Semarang

\section{KESIMPULAN}

Berdasarkan hasil kajian dan analisis untuk mengetahui pengaruh dari program pembangunan perumahan bagi rumah tangga miskin terhadap kondisi sosial dan ekonomi masyarakat di Kelurahan Sawah Besar, Kecamatan Gayamsari, Kota Semarang, maka dapat disimpulkan bahwa pelaksanaan program telah berhasil meningkatkan sebagian besar kondisi, yaitu sebesar $90 \%$, menunjukkan bahwa program ini secara umum telah berhasil meningkatkan kondisi masyarakat penerima bantuan, baik kondisi fisik, sosial, maupun ekonomi.

Persentase rata-rata dari analisa ketepatan sasaran berdasarkan kondisi rumah tangga sebelum pelaksanaan kegiatan adalah sebesar $31,50 \%$, dimana persentase tersebut masuk dalam kategori rendah, hal tersebut bukan dikarenakan bahwa rumah tangga penerima bantuan dari kegiatan ini tidak memenuhi kriteria rumah tangga miskin atau tidak tepat sasaran, tetapi, karena kriteria yang digunakan dinilai masih belum mampu menangkap gambaran kemiskinan, serta memberikan hasil yang bias terhadap keadaan sebenarnya. Oleh karena itu, perlu adanya revisi atau perbaikan dalam penentuan kriteria rumah tangga sasaran, karena dengan menggunakan kriteria rumah tangga miskin tersebut, tingkat sensitivitasnya perlu dipertanyakan, dimana variabel di dalamnya dapat berpotensi menimbulkan konflik, seperti pada luas bangunan rumah tangga yang menerima bantuan adalah seluas $8 \mathrm{~m}^{2} /$ orang, tetapi ternyata beberapa rumah tangga yang memperoleh bantuan memiliki luas bangunan $>8 \mathrm{~m}^{2}$, sehingga jumlah bantuan yang seharusnya untuk bangunan seluas $8 \mathrm{~m}^{2} /$ orang harus digunakan untuk bangunan dengan luas $>8 \mathrm{~m}^{2}$, yang akhirnya kekurangan dari bantuan harus diusahakan sendiri oleh masyarakat, dimana salah satunya dengan berhutang.

Oleh karena itu, kriteria rumah tangga sasaran yang lebih tepat adalah menggunakan kriteria kearifan lokal, dimana kriteria miskin ditentukan oleh masyarakat sendiri dengan diberi kewenangan untuk menentukan siapa yang berhak menerima bantuan, bukan secara intervensi dari pemerintah, untuk kemudian dilegalisasi melalui musdes/muskel, sehingga tidak akan timbul konflik di dalam masyarakat, serta dapat memunculkan simpati bahkan empati antarmasyarakatnya yang pada akhirnya dapat membangkitkan modal sosial yang ada di dalam masyarakat yaitu pemberdayaan dalam pelaksanaan pembangunan rumah dari para penerima bantuan, sehingga masyarakat tidak perlu berhutang dalam pelaksanaannya.

Hasil dari pelaksanaan program adalah mampu meningkatkan kondisi fisik dari para penerima bantuan sebesar $55 \%$, kemudian meningkatkan pula kondisi sosial masyarakat penerima bantuan sebesar $45 \%$, tetapi ternyata terhadap kondisi ekonomi mengalami penurunan sebesar $10 \%$. Adapun variabel kondisi ekonomi yang paling signifikan tidak berubah adalah pada parameter tingkat pengeluaran, dengan nilai hasil uji Wilcoxon yang cukup besar, yaitu 0,670, hal tersebut diakibatkan bahwa pengaruh dari pelaksanaan program terhadap pengeluaran responden, justru berbanding terbalik, dalam artian pengeluaran menjadi lebih besar dibandingkan sebelum adanya program, hal tersebut diakibatkan karena dalam pelaksanaan pembangunan/perbaikan rumah, banyak responden yang harus berhutang, sehingga mengakibatkan meningkatnya pengeluaran (berpengaruh negatif), karena tidak disediakan sharing dana dalam pelaksanaan pembangunannya.

Perubahan kondisi fisik bangunan sebagai hasil dari pelaksanaan program pembangunan perumahan bagi rumah tangga miskin tidak berpengaruh terhadap perubahan kondisi sosial, tetapi berpengaruh pada kondisi ekonomi. Hasil analisis tersebut memiliki arti bahwa program ini lebih berpengaruh secara langsung terhadap kondisi ekonomi utamanya bagi masyarakat yang memiliki usaha sampingan di sekitar rumah, dimana penerima bantuan yang memiliki mata pencaharian sampingan dengan adanya program ini, dapat lebih mengembangkan usahanya 
Tri Hapsari, M | Pengaruh Pembangunan Perumahan Bagi Rumah Tangga Miskin (Rtm) Terhadap Kondisi Sosial - Ekonomi Masyarakat Kelurahan Sawah Besar, Kecamatan Gayamsari, Kota Semarang

sehingga dapat meningkatkan pendapatannya. Dari program ini pula, ternyata sangat berpengaruh secara langsung terhadap tingkat pengeluaran, karena seperti yang kita lihat pada uji beda sebelumnya, bahwa program ini menimbulkan biaya hutang dari beberapa penerima bantuan, diakibatkan tidak adanya sharing dari pemerintah, sehingga perlu adanya adanya revisi atau perbaikan dalam penentuan kriteria rumah tangga sasaran seperti yang telah dijabarkan sebelumnya.

\section{DAFTAR PUSTAKA}

A Report Prepared For G15 And The National Housing Federation. 2014. Assessing the social and economic impact of affordable housing investment. London: Frontier Economic.

Budihardjo,Eko, 1994 . Percikan Masalah Arsitektur Perumahan dan Perkotaan.Yogyakarta : Gadjah Mada University Press

Republik Indonesia. 2008. Peraturan Menteri Perumahan Rakyat No. 22/PERMEN/M/2008 tentang Standar Pelayanan Minimal Perumahan dan Kawasan Permukiman. Sekretariat Kabinet RI. Jakarta.

Turner,J.F.C, 1976. Housing By People_Toward Autonomy in Building Environment. New York: Pantheon Books.

Undang-Undang No. 1 Tahun 2011 tentang Perumahan dan Kawasan Permukiman

Yudohusodo, Siswono. 1991. Rumah Untuk Seluruh Rakyat. Jakarta : Direktorat Jendral Cipta Karya Gambo,Y.L, O. B. Idowu and I. M. Anyakora. 2012. "Impact of Poor Housing Condition on the Economy of the Urban Poor: Makoko, Lagos State in View". Journal of Emerging Trends in Economics and Management Sciences (JETEMS).Vol. 3(4), pp: 302-307.

Friedman, Danny. 2010. Social impact of poor housing. United Kingdom : Ecotec 